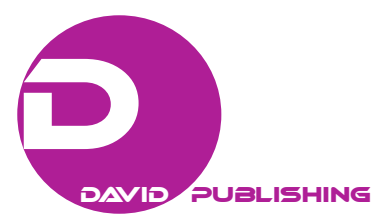

\title{
The Virus in Serresian-Posthumanist Sauce: A Hopeful Monster Parasite
}

\author{
Orsola Rignani \\ University of Florence, Florence, Italy
}

\begin{abstract}
Since the beginning of the COVID-19 pandemic, a tripartite blanket of disease/containment/return to normality has crystallized around the virus. But is it possible to grasp the frayed shirt of this blanket and gradually try to undo it? This is the attempt that this contribution makes. And that, drawing on a toolbox made up of the reflections, in this case converging between them, of Michel Serres and the posthuman on the dynamics inventive of new homination horizons, which the virus, beyond the contingency of its pathogenicity, as a hopeful monster parasite, can trigger.
\end{abstract}

Keywords: virus, parasite, hopeful monster, Michel Serres, posthuman

What is a parasite? An operator, a relation. This simple arrow intercepts. It intercepts organic messages in a living system. Noise, perhaps, but language as well, often living. All doctors have the same profession, as we see. Let them speak, cut, give injections ... they live and eat from the same profession. What is the parasite? A deviation, minimal to begin with, that can remain so until it disappears or that can grow until it transforms a physiological order into a new order. All sickness, all medicine, is parasitic in this new way. (Serres, 1980, p. 198)

\section{On the Dysfunctional Functioning: The Parasitic Virus}

The virus, an obligate parasite, from the first months of 2020 has become the background noise of our lives, that is, to say it with Michel Serres ${ }^{1}$, the interference, the disturbing element, the interruption, and at the same time also the start, however it is, of a change (Serres, 1980). Which - it is almost superfluous to observe - has aroused recursive and sometimes obsessive reviews of the shifts/extensions of its recognition/use (as an explanatory model) from the living to the inert, from the biological-medical to the informatics, to the processes of cultural globalization, the human impact on the planet, the subversion of ecosystems, the pandemic risks, the demographic increase; as well as its adjective expression of rapid and widespread diffusion, and so on (Marchesini, 2021).

Beyond commonplaces, the widespread approach and attitude towards it was in any case that of fear and the implementation of strategies to contain/extinguish it. But could it be otherwise? If, at first glance, the answer is negative, however, one could try to take up the challenge of overcoming contingency and point of view, listening to those who, like Michel Serres, in an unsolicited assonance with the orientations of the posthumanist perspective (Rignani, 2012; 2014; 2016; 2018; 2019; 2020), questioned themselves on alterity, on diversity, on discrepancy, on anomaly, pointing to a re-declination according to a dynamic of overcoming the

Orsola Rignani, Ph.D., assistant professor, Department of Humanities, University of Florence, Florence, Italy. Research fields: (history of) philosophical anthropology, philosophy of the posthuman, philosophy of the body.

${ }^{1}$ As regards the themes of this contribution, on Serres I recommend Rignani $(2012 ; 2014 ; 2016 ; 2018 ; 2019 ; 2020)$; Moser (2016); Dolphijn (2019); Watkin (2020); Aa. Vv (2020). 
immediate interpretation given from a single point of view. That is, according to an effort to synthetize by generalizing points of view (possibly also according to a retrospective or long-term perspective), in a synthesis rich in novelty, which does not intend to cancel the element but to complete it (Watkin, 2020).

So, what looked at in the here and now and from a single point of view seems not to/does not work, in the synthesis it does/makes it work.

And this is precisely the case of the parasite and therefore of the virus which is an obligatory parasite (but, in the Serresian perspective, it also the case of the lame, the frail, the disadvantaged, etc.) (Serres, 1999; 2015). Therefore, if there is no doubt - as Serres notes (2015) - that discontinuity, rupture of equilibrium, such as in this case those induced by the disease/virus/parasite, are tiring, unsetting, traumatizing, as well as tragic in relapses, one can still try to identify the potential for change and transformation: encounters, imbalances and contaminations are most of the time sources of novelty, while uncontaminated, balance, continuity mark repetition and sterility.

At this point, it is difficult to resist the temptation to recall here the Serresian suggestions, in a certain way converging with the posthumanist (Marchesini, 1996; 2009; 2014; 2019; 2020; 2021) ones $^{2}$, on the parasite as an abusive host, but with a broader ontological-ethical significance, as a universal relationship, a condition that precedes exchange and reciprocity, prerequisite of all existence. Serres (1980), in fact, recognized in parasitism the basic link between two entities, in the sense not simply that it is an elementary relationship, but that it is an element of the relationship; so that, the fundamental social relationship is parasitic.

The chain of parasitism is a simple relation of order, irreversible like the flow of the river. One feeds on another and gives nothing in return. Asymmetry is local on a chain and is propagated globally the length of a series, through transitivity. They make a line. In reality, the matter is more complex. [...] For the moment, we will remain at the level of the elements of the relation. For parasitism is an elementary relation; it is, in fact, the elements of the relation. The relation upsets equilibrium, making it deviate. If some equilibrium exists or ever existed somewhere, somehow, the introduction of a parasite in a system immediately provokes a difference, a disequilibrium. Immediately, the system changes; time has begun. Change comes from a rupture in equilibrated exchanges. Change is the disequilibrium of exchanges. [...] Without a parasite - that is to say, without asymmetry or disequilibrium - there is no irreversible, no change emerges, and time is unknown. (pp. 182-183)

The parasitic relationship, therefore, is original because it precedes contracts and laws; and all the links of exchange and reciprocity are precisely transformations of a primitive parasitism. The parasite, in which the prefix para-, close to-, expresses the measurement, relationally, of a distance from- (ivi, p. 144), is ontologically a deviation from the equilibrium that inaugurates (birth, invention, etc.); it is a relationship operator that fluidizes the separation between subject and object, bringing out mutuality, partnership, contractuality aimed at symbiosis; just as, ethically, it is a condition of possibility of exchange and reciprocity, not only to be supplanted by the latter, but also by remaining as a catalyst and flywheel of gift, gratuitousness, or perhaps of parasitic symbiosis.

[...] Inclination is the beginning of the world. One can never praise enough; here is the list of excess, fault, difference. It appears in the logic of reasoning [...]; it appears in language [...]; it appears in order [...]; it appears in exchange and in money $[\ldots]$; it appears at the edge of the beam [...]; it appears now in physical systems $[\ldots]$; it appears in living systems

\footnotetext{
2 Although I have always doubted, and continuing to do so, the heuristic profitability of the "assessment" of Serres's posthumanism or not, especially considering the fluidity of the posthuman and the intellectual independence of Serres himself, I have nevertheless found and highlighted isomorphisms between them in relation precisely to the conception of human and of the interface between it and the world. I have developed these positions specifically in Rignani $(2012 ; 2014 ; 2016 ; 2018 ; 2019 ; 2020)$.
} 
[...]. The prefix para is counted, calculated, weighed in its difference from equilibrium. [...]. The parasite has a relation with the relation and not with the station. (ivi, pp. 32-33)

In all this, quite evident is the assonance with the posthumanist horizon ${ }^{3}$, for which neither the human nor the other-than-human can be thought of disjunctively, in a virus-free dimension, but rather inter-implicated in complex synergies, in dynamics of permeability, of hybridization, of infiltration, of infection, of contamination, in which the "other", the non-conforming, the pathogen, the dysfunctional can return to make it work. That is, it can emerge as a flywheel and catalyst of new characters, possibilities, moral resources for the human in the world and with the world (Marchesini, 1996; 2009; 2014; 2019; 2020; Braidotti, 2013; 2021; Haraway, 1991).

We cannot, in fact, imagine ourselves in a germ-free dimension, because every organism is an ecosystem and life is always a laboratory of relationships, and viruses play an important part in this network. We have the impression that a virus is something objectively negative, against which we must defend ourselves, and yet this view is not only incorrect, but risks inspiring policies of everyday medication and control of socio-ecological relations that would have the opposite effect. (Marchesini, 2021, p. 55)

Paradoxes? If taken literally, at a time like this when the COVID-19 pandemic is still more or less fire in the ashes, they probably are; however, the suggestions that can be gathered from these items are roughly two; interconnected. One is the approach of inclusion by generalization of points of view (Watkin, 2020), which can help to overcome the epidemiological contingency reconsidering its pathogenicity in the long term.

The other, which, so to speak, is the corollary of the previous one, is the general impulse to exit the separative idea of the different, the pathogen, the dissonant, the non-conforming, and the cogency of their exorcization, correction, neutralization. According to the consideration that it is not possible to know a priori where the exception goes, and that in any case, it is not even legitimate or wise to ask oneself, because it goes its own way which can involve an immediate and lasting fortune or a temporary disavowal and a sudden fortune in uncertain times and places or even irreversible oblivion (Serres, 2015). And in any case what matters is recognizing it, and therefore letting the multiplicity, the inventiveness, the variety emerges beyond the point of view (ibidem).

However, the dimension of contagion may perhaps go beyond its epidemiological perimeter and assume a paradigmatic dimension, providing us with new models for interpreting our presence in the world. It is understandable that, in the face of an emergency of epochal proportions, defensive reactions will prevail and instruct the immediate strategies of containment, but it is indispensable, later on, to look beyond the contingency. We are a virus for the planet, but at the same time we are subject to continuous infections, and it is those infections that have designed the undoubted masterpiece that we call the human condition. Having greater awareness of our hybrid dimension can help us to rediscover the value of being in a relationship and to understand that the extension of the human is not limited to the contours of our skin. (Marchesini, 2021, p. 57)

So, defense, containment, but also, so to speak, starting a process of recognition/coexistence, because perhaps everything works like a virus and the dysfunctional can make it work.

\footnotetext{
${ }^{3}$ Should be remembered here that Posthumanism critically rethinks the anthropocentric-humanist-dualist vision, according to which the human species, the Anthropos, is distinguished, by superiority, compared to other species on the ontological level (the human essence is superior to the others), epistemological (human knowledge is the model and reference of other forms of knowledge) and ethical (man is the only bearer of moral values), and Man is exclusively the male, white, Western, educated, which, as such, is the center (of reference) of the world, and he is separated from all the rest. For an overview of the various orientations within the posthuman, I refer to some recent manual and glossary contributions as well as to the bibliographic references contained therein: Braidotti \& Hlavajova (2018); Rosendahl Thomsen \& Wamberg (2020); Baioni, Cuadrado Pareyas \& Macelloni (2021); in addition, an incisive synthesis of all these topics is provided by Ferrando (2019).
} 


\section{The Virus to the Test of the Hopeful Monster}

Faced, therefore, at the cul de sac of a public attention still largely attested to the trinomial disease/containment/return to normality, as well as fed and substantiated by automatisms that inhibit awareness and a disenchanted approach, the question about novelty, and possibly on how to read it and a search for a loophole, or at least a hole from which to gain a slightly more perspective view, become urgent needs at this point. But the urgency, as often happens, pushes you to rummage even in the most hidden corners, to open drawers locked by others, to tear off flaps from sealed envelopes, to listen to words made voiceless by desuetude. And here we happen once again to hear, among these, Serres's words, in this case, on the untimely, that is, on the inventor, so called by him for his ability to rediscover forgotten and/or ignored and yet fruitful visions of the world (Serres, 2014). Immediately one comes to ask and at the same time answer that the untimely/inventor is Serres himself, with his thinking by relating disparate elements, relating to multiplicity (ivi, p. 366), starting from what is believed to be originally deconstructed, different, contradictory (Serres, 2021); with his saltational vision of life and thought ${ }^{4}$, in which monsters, hopeful if the blow succeeds, and hopeless otherwise (Serres, 2014), attempt the blow; with his idea of the power of the little one, which can become the engine of a higher energy (Serres, 2021), and the contre (against) that can become avec (with) (ivi, pp. 231-247).

What to say? And what if this untimeliness were propulsive force towards the exit from the bottleneck? What if the still rather unknown Serres, with his non-mainstream ideas (Polizzi, 1990; Dolphijn, 2019; Watkin, 2020; Rignani, 2012; 2014; 2016; 2018), were the ram's head capable of opening a hole in the wall of the aforementioned trinomial? What then would become of the disease/virus (with the related containment strategies) and the return to normality?

A plausible answer could be attempted by resorting to the image that Serres himself uses to represent his work: a fluid forest in perpetual motion (Serres, 2014), where sliding (fluidity) and incessant movement are oxymorically attributed to the fixity/stability (of the trees/forest). For which, disease/virus, treatment, normality would jut out as fluid fixities in the act of taking the leap, of attempting to strike; that is, in a process of deactivation on the substantial level and reactivation on the potential one, they would emerge as a bifurcation point, full of possibilities, which can hopefully turn towards the hopeful monster, the evolutionary stage that can produce a new line of evolution, or even towards the hopeless monster, the unsuccessful shot, the siding (ibid.). In any case, it remains that, with Serres, the cards are messed up: As mentioned, what is commonly considered different, contradictory, deconstructed, heterogeneous - read disease/virus — can trigger/enter into relational dynamics, inventive of new dimensions of homination; the small, the infinitesimal — read virus — can induce a dynamism in which the opposition can become co-belonging and coexistence; the transformations do not take place through the accumulation of little gradual changes — read normality/return to normality—but thanks to big morphological leaps (ibid.).

The filter of Serresian untimeliness, therefore, discolors, liquifies, de-substantiates the trinomial disease/containment/return to normality and so to speak it transfigure and refracts it in a kaleidoscopic-metamorphic perspective for which the virus becomes a monster, that is something extraordinary,

\footnotetext{
${ }^{4}$ Serres reads the trend of life and thought through the filter of the saltational theory of evolution of Richard Goldschmidt, as known, the first scientist to use the term hopeful monster to express the idea of macromutations, morphological leaps in evolution (Goldschmidt, 1940).
} 
rupture, turning point, root/power of change (at an ecological, evolutionary, economic-global level, social relations, technological hybridization, corporeality, human awareness and self-perception, etc.); perhaps hopeless, but perhaps also hopeful precisely.

The general message that can be gathered from this is that hybridization - in this case, the interaction with the virus-, its different levels, the awareness of all this, are always sources of change/novelty. And that therefore normality is radical change, and the return to it is the drastic change consisting in becoming aware of the change itself.

In the backlight of the Serresian reflection, the virus, especially for and with its pandemic significance, ultimately assumes the character/role of monster, that is, of monstrum, prodigy, and therefore of exception as well as rupture, which, as an etymological derivative of monere, conveys the message/warning (of awareness) of the change, which is however "bivalent".

So, if all this obviously does not question the essentiality of the continuous implementation of containment strategies, it can still constitute the stimulus to the awakening of critical attention, the suggestion of an "untimely" rethinking of what is given, hastily and for granted, for illness and for normality.

And anyway, why not make the leap to think that life is made up of leaps? Why not recognize the fluid forest in constant motion? Why not believe the monsters? After all, why not trust that they are hopeful?

Once again Serres-Pantope/Passe-Partout (Serres, 2014) can be an effective passepartout...

\section{References}

Aa. Vv. (2020). Michel Serres. Hommage à 50 voix. Paris: Le Pommier.

Baioni, E., Cuadrado Pereyas, L. M., \& Macelloni, M. (Eds.). (2021). Abbecedario del postumanismo. Milan: Mimesis.

Braidotti, R. (2013). The posthuman. Cambridge: Polity Press.

Braidotti, R. (2021). Posthuman feminism. Cambridge: Polity Press.

Braidotti, R., \& Hlavajova, M. (Eds.). (2018). Posthuman glossary. London, New York: Bloomsbury Academic.

Dolphijn, R. (Ed.). (2019). Michel Serres and the crises of the contemporary. London, New York: Bloomsbury Academic.

Ferrando, F. (2019). Philosophical posthumanism. London, New York: Bloomsbury Academic.

Goldschmidt, R. B. (1940). The material basis of evolution. New Haven CT: Yale University Press.

Haraway, D. (1991). Simians, cyborgs, and women: The reinvention of nature. London: Routledge.

Marchesini, R. (1996). Il concetto di soglia. Una critica all'antropocentrismo. Rome: Theoria.

Marchesini, R. (2009). Il tramonto dell'uomo. La prospettiva post-umanista. Bari: Edizioni Dedalo.

Marchesini, R. (2014). Epifania animale. L'oltreuomo come rivelazione. Milan: Mimesis.

Marchesini, R. (2019). Estetica postumanista. Milan: Meltemi.

Marchesini, R. (2020). Essere un corpo. Modena: Mucchi Editore.

Marchesini, R. (2021). The virus paradigm: A planetary ecology of the mind. Cambridge: Cambridge University Press.

Moser, K. (2016). The encyclopedic philosophy of Michel Serres: Writing the modern world and anticipating the future. Augusta GE: Anaphora Literary Press.

Polizzi, G. (1990). Michel Serres. Per una filosofia dei corpi miscelati. Naples: Liguori.

Rignani, O. (2012). Umano? Una domanda per Italo Calvino e Michel Serres. Fidenza (Pr): Mattioli 1885.

Rignani, O. (2014). Emergenze "post-umaniste" dell'umano. Prove di analisi storico-comparativa dal presente al passato e ritorno. Milan: Mimesis.

Rignani, O. (2016). Emergenze "post-umaniste” del corpo. Una prova di analisi “orizzontale” via Michel Serres. Milan: Mimesis.

Rignani, O. (2018). Metafore del corpo post-umanista: Michel Serres. Milan: Mimesis.

Rignani, O. (2019). Toward a posthuman humanism: Serresian federative humanism between natural contract and political ecology. Philosophy International Journal, 2(1), 1-6.

Rignani, O. (2020). The relevance of Michel Serres's idea of bodily hominescence for a convergence of posthumanism and transhumanism: A trans/posthuman body. Philosophy Study, 10(2), 119-126. 
Rosendahl Thomsen, M., \& Wamberg, J. (Eds.). (2020). The Bloomsbury handbook of posthumanism. London, New York: Bloomsbury Academic.

Serres, M. (1980). Le parasite (The parasite). (L. R. Schehr, Trans.). Minneapolis MN: University of Minnesota Press. Serres, M. (1999). Variations sur le corps (Variations on the body). (R. Burks, Trans.). Minneapolis MN: Univocal. Serres, M. (2014). Pantopie: de Hermès à Petite Poucette. Paris: Le Pommier.

Serres, M. (2015). Le Gaucher boiteux. Puissance de la pensée. Paris: Le Pommier.

Serres, M. (2021). La fontaine. Paris: Le Pommier.

Watkin, C. (2020). Michel Serres: Figures of thought. Edinburgh: Edinburgh University Press. 